\title{
The Evaluation of the Learning Management System Implementation for Functional Distance Learning of Basic Tax Instructor
}

\author{
Mohammad Djufri ${ }^{1}$, Aniek Juliarini ${ }^{2}$ \\ mohammad.djufri@kemenkeu.go.id ${ }^{1}$, aniek.juliarini@kemenkeu.go.id ${ }^{2}$ \\ Badan Pendidikan dan Pelatihan Keuangan, Indonesia ${ }^{1,2}$
}

\begin{abstract}
This research evaluated the implementation of a Learning Management System (LMS) designed for the Functional Distance Learning (DL) of Basic Tax Instructor. The object of study is the four classes of Basic Tax Instructor Functional DL at Jakarta, Yogyakarta, Pontianak, and Manado, Indonesia. The primary data were obtained from questionnaires submitted to 115 participants and the secondary data in the form of graduation data. The research method is descriptive qualitative. An essential finding of this study is that the LMS is good, easier to access, to learn, provides complete, real-time, has a nice and attractive look, creative, engaging, and accessible. The problem with accessing the LMS is signal/network issues. For improving it, some participants suggest the LMS make it more attractive, always updated, more easy to access, added some feature, accessible for all the time, it integrated with institution learning center (Kemenkeu Learning Center), and make more simple.
\end{abstract}

Keywords: ADDIE, covid-19, distance learning, implementation LMS, learning management system.

\section{Introduction}

The Covid-19 pandemic has forced people to keep their distance, avoid face-to-face meetings and stay away from crowds, but work and learning still have to go on. The implementation of education and training must also quickly adapt to changes. Information technology, which has developed rapidly at this time, is beneficial in overcoming this issue. Because face-to-face learning is not possible, distance learning is a solution during this pandemic and may even continue to be done if it is more effective and efficient. 
However, the learning process certainly requires interaction between the learner and the teacher. The exchange of learners and teachers can occur in different places at the same time or in other places at different times. The learning process in which the learner and teacher are in various areas is known as distance learning. Warsito (2011) says distance learning and training is a learning model that gives students the freedom to learn without being bound by space and time with as little help as possible from others [1]. Bozkurt (2019) stated that distance education (DE) and open and distance learning (ODL) transform and adapt according to changing paradigms [2]. Because the place is different, we need media to learn media that can be done by using information and communication technology.

Currently, various information technology products are available to help teachers and students to be able to do learning [3]. The internet is a learning resource that provides a lot of information and is easy to access. However, it will be more challenging to find suitable and reliable learning materials because of the ease of sharing learning materials [4]. Therefore, it is necessary to create a learning resource built and filled by competent and authorized parties. This learning resource can be made on a Learning Management System (LMS).

Most learning management systems (LMS) are web-based, built using various development platforms such as Java/J2EE, Microsoft.NET, or PHP. Most systems are commercially developed and have a commercial software license, but some systems have an open-source right. Moodle, for example, is widely used as an open-source code system, and WebCT (Blackboard) is widely used as a commercial program. Researchers' search for new LMS will change based on needs and technological advances [5]. The internet today offers many tools and application packages for educators that can be used at all stages of teaching, and these tools increase the effectiveness and efficiency of teaching [3]. Meanwhile, according to Soykan \& Şimşek (2017), LMS itself is the main component to implement distance education effectively [5]. So, distance learning media using LMS becomes something that is needed, so that learning can run as expected.

Considering the increasing need to build LMS, research on developing LMS-based elearning is very feasible. According to Rabiman et al. (2020), the LMS assessment is based on its benefit, function, visual communication, learning design, material content, and language and communication. The use of LMS increases the satisfaction and quality of learning [6]. Currently, Google offers a service to create an accessible website because it does not require programming language skills, and it is free, namely Google Sites. Based on the LMS based on Google Sites, teachers can create classical guidance media and can create positive content that students can utilize via smartphones. Google Sites can also be integrated with other Google services, such as Google Forms, Google Sheets, Google Slides, and other services outside of Google, such as Padlets. Learning materials in pictures, animations, interesting video shows, or short cinemas can be used in class or outside the classroom with smartphone facilities and internet networks [7]. Given the many facilities offered by Google Sites, the LMS based on Google Sites is an alternative as a distance learning media.

One of the training organized by the Tax Education and Training Center (Pusdiklat) of the Ministry of Finance of the Republic of Indonesia is the Distance Learning (DL) Functional Basic Tax Instructor. In implementing the Functional DL of Tax Instructor in 2021, a Learning Management System based on Google Sites has been built and applied in several learning classes. Juliarini \& Kurachman (2020) say that the challenge in designing distance learning is how to keep learning compelling and exciting even without direct meetings between teachers and students [8]. Therefore, studying whether the Learning Management System of the Functional DL Basic Tax Instructor built can make learning more accessible, more interesting, 
and efficient to achieve learning objectives. Evaluation of the implemented learning design is needed to develop and improve the LMS so that in the next period, it will be better.

\section{Literature Review}

Learning Management System (LMS) is a web-based application that can be accessed with a web browser from anywhere as long as there is an internet connection. According to Llantos \& Justina E. Estuar (2018), LMS provides tools for teachers to create online learning sites and provides access for learners to access learning materials [9]. There is an encouragement to use LMS from the environment in improving the teaching and learning experience. All LMS systems are highly dependent on available technology, information, and communication infrastructure. Most universities in the United States, United Kingdom, Canada, and Australia, including 28 universities in Saudi Arabia, use different LMS systems [10].

Zheng et al. (2018) underlined that organizational support and technical support play a significant role in developing LMS, resulting in perceived benefits from using LMS. The implication is that universities can increase LMS use and achieve more effective outcomes in web-based learning distance learning [ 11]. LMS enhanced with the Internet of Things (IoT) will start a new generation of learning system management. The advancement of intelligent devices, new applications, new strategies, and new inventions will change the LMS style in the future [12].

Currently, many available LMS is ready to be used; one of them is LMS based on Google Sites. Setyawan's research (2019) shows that learning media innovation using the Google Sites website is attractive to teaching participants to motivate them to participate in learning actively. Google Sites can also create forms and other instruments as assessments and evaluations integrated on a completed page. Mukti (2020) stated that Google launched Google Sites to build classrooms, schools, or other websites by combining various information in one place, including videos, presentations, attachments, and texts, which can be shared according to the user's need [13]. One of the advantages of this Google product is that this product is provided free so that from a cost perspective, it is not an issue for teachers and students to use it.

Google Sites can also help teachers and students to show their work to others by uploading their work. This will be very interesting because it will encourage students to continue to create better jobs since knowing that their work will be published. Maheshwary \& Bhandari (2019) said that the more the audience, the more effort they will put into making even more products [14]. Google Sites as an LMS creation platform has several advantages as follows:

1. Can attract educators/teachers because of its convenience. Technically, making website media using Google Sites is very easy; no language skills or programming code and HTML are needed; click, drag, and drop what you want to display on the LMS site. The templates from Google-Sites are pretty numerous and attractive, and users can easily customize them according to their wishes.

2. Google Sites is rich in content because it integrates with other Google services. Users can insert images, videos, documents, spreadsheets, presentations, forms, jamboards, photo slideshows, and calendars. Some applications provided by Google can also be integrated into Google Sites, such as pallet, youtube, and quizizz. In Google Sites, there is a search feature, so users can also search on these Google Sites content pages and find pages and various documents quickly, just like on Google.com. 
3. Building a site with Google Sites allows each teaching team member to work together to fill in the content. The settings are elementary to do just by setting the owner's permissions and collaborators who can edit the LMS page.

4. Lots of learning activities are provided by Google Sites. Google Sites can be integrated with other Google services or services outside of Google combined with various learning media. Learners can learn training materials through modules, broadcast materials, or learning videos. Teachers can integrate it with Google Forms, Google Sheets, or Google Classroom as a learning evaluation material. Likewise, to administer the results of student discussions, it can be integrated with pallets.

5. Easy access for learners. Google Sites provides services so that the LMS site can be accessed by users in three modes, namely mobile phones, tablets, or computers. This provides flexibility and convenience for users to access it.

6. Building an LMS using Google Sites is free. LMS developers can use Google Sites to create a complete learning site without hosting or buying a domain, which requires considerable funds. With Google Sites, you can even create an LMS site for free. The capacity provided by Google for each LMS account is 15 GB, along with the Google Sites application and other Google application services that can be integrated into Google Sites. Several other free applications such as Youtube and Padlet can also be integrated into Google Sites so that LMS content will become more complete and exciting.

Aside from its advantages, Google Sites also has disadvantages, especially the unavailability of tools/plugins that can manage the users, including the access setting of each user. In freeware, Google only provides $15 \mathrm{~GB}$ of storage space; of course, additional storage space is needed to keep more learning materials.

According to Rusdi (2018), products for learning currently popularly designed and developed are teaching materials, teaching multimedia, teaching aids, student worksheets, and assessment instruments [15]. Rusdi (2018) wrote that the development of learning multimedia was studied in detail by Lee \& Owens (2004) in their book "multimedia-based Instructional Design," with the development steps through the main ADDIE framework (Analysis, Design, Development, Implementation, and Evaluation) as illustrated with Figure 1 below.

\section{Core Elements of the ADDIE Model}

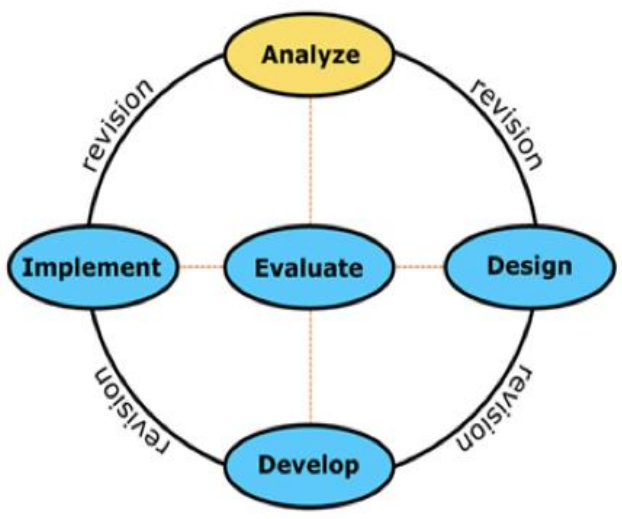

Figure 1. Five Steps of ADDIE Learning Design Source: https://lpmpjatim.kemdikbud.go.id/ 
Nichols Hess \& Greer (2016) cites Branch (2009) that the ADDIE instructional design framework has five phases.

1. Analyze the learning situation (Analysis);

2. Design goals and principles to solve problems in learning situations (Design);

3. Develop resources to meet this specification (Development);

4. Apply learning resources in learning situations (Implementation); and

5. Evaluate how these resources meet instructional needs (Evaluation). [16]

The process of developing learning media requires expert testing, individual research subjects, implementation on a limited scale and a wide-scale (in the field), and revisions to create the product design better so that the product developed meets the criteria as a good product and is empirically tested [17]. Rusdi (2018) reminds us that designing and producing something innovative with a well-thought-out concept requires adequate knowledge and skills. If we want to develop multimedia learning using specific software, we need to cover the following things.

1. Technically, they can operate the software optimally and know the limitations of the software's capabilities so that it may need to be combined with other software.

2. I am learning design concepts and procedures. It is essential that the developed multimedia considers the principles of teaching and learning to be used as information media.

3. Mastery of the material and understanding of cognitive load theory. Based on cognitive load theory, to achieve effective learning, interactive media development should reduce the processing of extraneous cognitive load, regulate the processing of intrinsic cognitive load, and help develop germane cognitive load processing.

4. Design and development research is group research. The special competence of each team member characterizes the resulting product.

The problems of designing and developing their models are: 1) what are the specifications of the models that have been designed and developed?; 2) how changes have been made to the existing model?; 3) how are the components and sequences of the models that have been generated?; and 4) what is the impact of using the model? [15]. LMS is a learning medium that is in line with the development of learning technology. However, in the development of this LMS, it still refers to the learning design created by preparing learning design, such as the ADDIE framework.

\section{Previous research}

Rabiman et al. (2020) stated that the development of LMS-based learning divides the development model into three phases: phase I needs assessment; phase II, design; and phase III, design and implementation. Overall evaluation and revision were done on the three stages of the development model [6]. Setyawan (2019) designs the development plan by adapting the ASSURE development model, including Analyze, State Objective, Select Method, media and materials, Utilizing media and materials, requiring learner participation, and Evaluating. Besides being called a design for teaching and learning activities, the ASSURE model development design is also a class-oriented media development model. There are six stages in this development model, which are: 1) Analyze the characteristics of students as learning subjects (Analyze); 2) Establish media standards and objectivity (State Objective); 3) choose a strategy, the use of technology and materials (select method, media, and material); 4) use of media and material technology; (Utilize media and materials) 5) Require student participation, 
in this case, requires implementation as a form of media testing in class (require learner participation); 6) evaluate the media that has been tested as a basis for making improvements (Evaluate).

According to Kumbhar (2020), building a website or portal using Google Sites is accessible and user-friendly [18]. Setyawan's research (2019) shows that class-oriented classical guidance services using the Google Sites website are accepted and feasible to be implemented. Awuah (2015) states that learning uses Google Apps for Education (GAFE), which mainly uses Google Sites. $84 \%$ of science students said their learning performance had increased, and $91 \%$ of students were satisfied with the learning compared to traditional methods that used little or no technology [19]. Regarding the google-site, Widodo (2017) argues that Google Site is one of the LMS that has been proven to be used in learning mathematics and improving primary school pre-service teachers [20]. In distance learning, research by Juliarini \& Kurachman (2020) concluded that the Tax Instructor Service DL at BDK Cimahi in August 2020 was adequate. Still, there were network issues in the implementation of learning. In this case, the reliability and availability of the internet network were some of the things that should be considered so that long-distance learning runs well[8].

\section{Research Method}

This research aims to obtain information related to perceptions and opinions of learning participants and teachers' views on using the Learning Management System for Functional Distance Learning of Basic Tax Instructor. Statements and inputs obtained will be submitted to the LMS creator to be used as material for improvement. Research data is in the form of primary data and secondary data. Preliminary data were obtained from questionnaires made in google sheets given to teachers and participants and observation notes made by researchers who were also teachers in both classes, in the form of the score of learning participants' activities. Secondary data in the form of participant data and passing grade data, as well as literature study. The research object is the Functional DL of Basic Tax Instructor, held in four locations spread across various regions in Indonesia, as shown in Table 1.

Table 1. Research Object

\begin{tabular}{clcc}
\hline No & \multicolumn{1}{c}{ Learning Organizer } & Date & Participant \\
\hline 1 & BDK Pontianak & 18-26 January 2021 & 24 \\
2 & BDK Manado & 15-23 February 2021 & 30 \\
3 & BDK Yogyakarta & 01-09 March 2021 & 32 \\
4 & Pusdiklat Pajak & 01-09 March 2021 & 32 \\
5 & Total & & 118 \\
\hline
\end{tabular}

Source: Tax Education and Training Center, 2021

Table 1 shows that the research object is the participants in four classes with four different training locations. Here, we do hope that a complete input/response can be obtained. Researchers also teach in these four classes to be directly involved in learning and observe the class. 
This research is a research design and development of learning media using the ADDIE method, specifically at the evaluation stage. This stage pays attention to the opinions and inputs of its users, which are the learners, obtained through a questionnaire made through the google form as reference material to provide suggestions/plans for improvement of the LMS media that has been formed. Data analysis was done qualitatively descriptive.

\section{Results and Discussion}

\section{Training Program}

The 2021 Basic Tax Instructor Functional Distance Learning Training Program is developing the previous year's program, 2020, after undergoing adjustments, especially in additional subjects and additional learning hours. This DL is intended for candidates for Tax Instructor Functional Officers. The material and the number of learning hours provided are as follows.

Table 2. List of Subjects

\begin{tabular}{clrrr}
\hline \multirow{2}{*}{ No } & \multicolumn{1}{c}{ Material } & \multicolumn{3}{c}{ Number of Sessions } \\
\cline { 3 - 5 } & & Sync & Async & Sum \\
\hline 1 & Management of the Implementation of Tax Instructor & 13 & 3 & 16 \\
2 & Activities & 10 & 0 & 10 \\
3 & Tax Service Administration & 12 & 3 & 15 \\
4 & Tax Instructor Methods and Techniques & 18 & 3 & 21 \\
5 & Communication Ability & 10 & 0 & 10 \\
6 & Introduction to Contact Center Management & 2 & 0 & 2 \\
7 & Lecture I: Current Policy on Instructor & 2 & 0 & 2 \\
& Lecture II: Administration System and Credit Score & & & \\
8 & Provisions for Functional Tax Instructor & 67 & 9 & 76 \\
& Total & & & \\
\hline
\end{tabular}

In Table 2, it can be seen that most of the learning (88.16\%) was done in synchronization, which was done from 08.00 WIB to 17.00 WIB with two coffee breaks for 15 " and one lunch and prayer break for 60". Asynchronous learning has a total of 9 sessions (11.84\%) done at night for 3 hours (135 minutes) in 3 days, starting at 19.00 WIB to 21.15 WIB. In this session, participants work on assignments related to learning materials and prepare presentation materials for the final exam.

The final exam of the Functional DL of Basic Tax Instructor is in the form of a practical exam, and all have been done in 5 hours of learning. Practical exams are conducted online/live, where each participant is asked to make a presentation for 10 minutes/participant, by applying all the theories that have been given, which are the Analysis of the Implementation of Instructor Activities, session plans, activities checklist, infrastructure checklist, broadcast materials, and application of presentation theory. The exam time is 5 hours. To be efficient, participants were divided into two groups, where a teacher as an examiner accompanied each group.

All learning events for the Basic Tax Instructor Functional DL are done within seven working days. Participants were divided into three groups on the last day, and each group presented a performance containing tax counseling materials. This event is called the Gemilang 
Show. In this session, all participants brought out their abilities well to collaborate to give exciting performances.

\section{Learning Management System}

In the previous year, learning materials were stored on a g-drive that all teachers, participants, and organizers could access. This method is considered less effective and less attractive. In 2021 a Learning Management System was created using the google-sites which contains all learning materials and administration, videos, quizzes, questionnaires, assignments, discussion rooms, etc. The appearance of the primary Tax Instructor Functional LMS is presented in Figure 2.

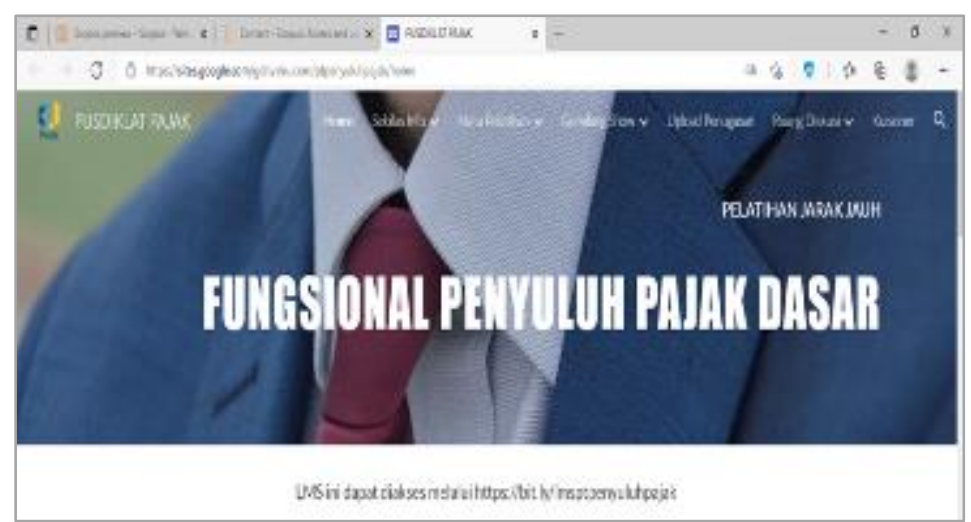

Figure 2. Learning Management System DL Functional Basic Tax Instructor

In Figure 2, we can see the LMS display, where there is a Home menu, Info, Courses, Gemilang Show, Assignments Upload, Discussion Rooms, and Questionnaires. LMS also provides learning videos connected to YouTube or videos uploaded directly to the LMS, quizzes, and questionnaires with g-forms. Assignments are uploaded in the form of a drive link from each participant's work and a discussion room in the form of a pad where each participant can paste the results of their discussion.

\section{Demographics of participants}

The total number of learning participants in the four classes is 118 people, which are 30 people in BDK Manado, 24 in BDK Pontianak, 32 in BDK Yogyakarta, and 32 in Pusdiklat Pajak Jakarta. Among 118 participants, the number of male participants was 64 (54.24\%) and 54 female participants $(45.76 \%)$. Although the implementation of education is spread across several regions in Indonesia, it turns out that almost all participants take lessons from Java (only two people who follow from positions outside Java). This is because most of the participants' workplaces are in Java, although training centers manage their training outside Java. This is possible because, in principle, DL can be done from anywhere. Based on the incoming data, out of 118 participants, 115 participants filled out the questionnaire or $97.45 \%$. The profile of 115 respondents is as shown in Table 3. 
Table 3. Socio-Demographic Characteristics of the Respondents

\begin{tabular}{|c|c|c|c|c|c|c|c|}
\hline \multirow{2}{*}{ No } & \multirow{2}{*}{$\begin{array}{l}\text { Demographic } \\
\text { Characteristics }\end{array}$} & \multicolumn{4}{|c|}{ Participants } & \multirow[b]{2}{*}{ Total } & \multirow[b]{2}{*}{ Percentage } \\
\hline & & Man & Ponti & Yogya & Jkt & & \\
\hline \multirow{4}{*}{1.} & Gender & & & & & & \\
\hline & Male & 16 & 10 & 16 & 22 & 64 & $54,24 \%$ \\
\hline & Female & 14 & 14 & 16 & 10 & 54 & $45,76 \%$ \\
\hline & & & & & & 118 & \\
\hline \multirow{7}{*}{2.} & Age & & & & & & \\
\hline & $25--30$ & 2 & 2 & 1 & 3 & 8 & $6.96 \%$ \\
\hline & $31--35$ & 10 & 7 & 10 & 8 & 35 & $30.43 \%$ \\
\hline & $36--40$ & 8 & 7 & 10 & 3 & 28 & $24.35 \%$ \\
\hline & $41-50$ & 9 & 4 & 9 & 13 & 35 & $30.43 \%$ \\
\hline & $>50$ & 0 & 4 & 2 & 3 & 9 & $7.83 \%$ \\
\hline & & & & & & 115 & \\
\hline \multirow{6}{*}{3.} & Position & & & & & & \\
\hline & Account & 25 & 16 & 24 & 19 & 84 & $73.04 \%$ \\
\hline & Representative & & & & & & \\
\hline & Structural Officer & 3 & 2 & 2 & 2 & 9 & $7.83 \%$ \\
\hline & Klip Agent & 1 & 6 & 6 & 9 & 22 & $19.13 \%$ \\
\hline & & & & & & 115 & \\
\hline
\end{tabular}

Based on Table 3, it can be seen that most of the participants are between the ages of 31-50 years old. Apart from that, 9 participants were over 50 years old, and 8 participants were 25-30 years old. Most of the participants (86.17\%) aged 31-50 years old were born from 1971 to 1990 , which means that most of them are X Generation and Y Generation. X Generation is the generation born from 1965 to 1980 . X Generation is the generation born in the early years of developing technology and information such as PCs (Personal Computers), video games, cable $\mathrm{TV}$, and the internet. Y Generation is known as the millennials. Y Generation uses many instant communication technologies such as email, SMS, instant messaging, and others. At the same time, most of the participants' positions are executors as Account Representatives, who in their daily work have a lot to do with taxpayers, so that they have pretty good technical skills.

\section{The most exciting and valuable System Management Learning Menu}

In LMS DL Basic Tax Instructor, there are various menus including learning materials for Management of the Implementation of Instruction Activities (MPKP), Instruction Methods and Techniques (MTP), Communication Ability (Kom), Administration and Tax Services (ALP), Introduction of Management Contact center (PMCC), discussion rooms, pallets, and teacher profiles. Participants were asked which menu was the most interesting and useful. Participants' answers are presented in Figure 3. 


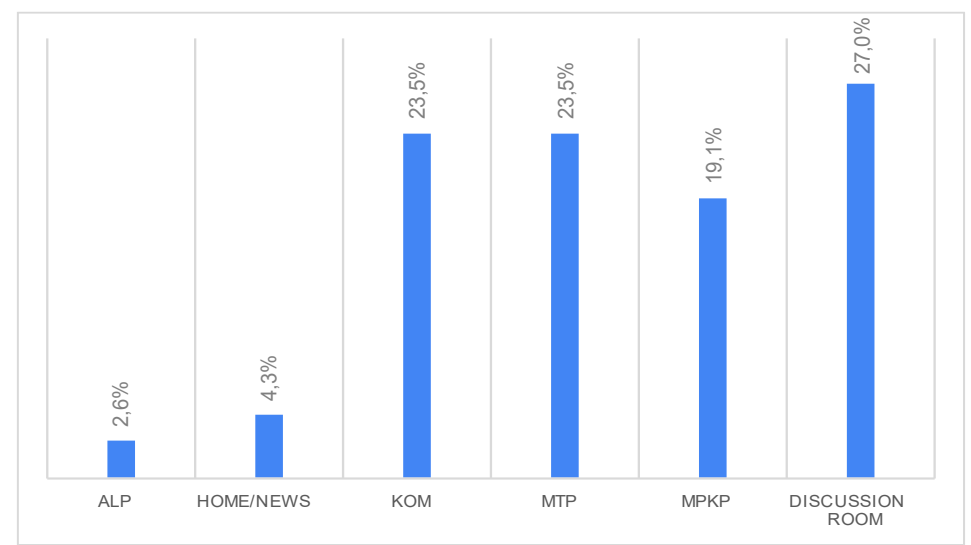

Figure 3. The Most Interesting and Useful LMS Menu

\section{Advantages of LMS DL Functional Basic Tax Instructor}

According to participants, the LMS that has been provided has several advantages, as presented in Figure 4.

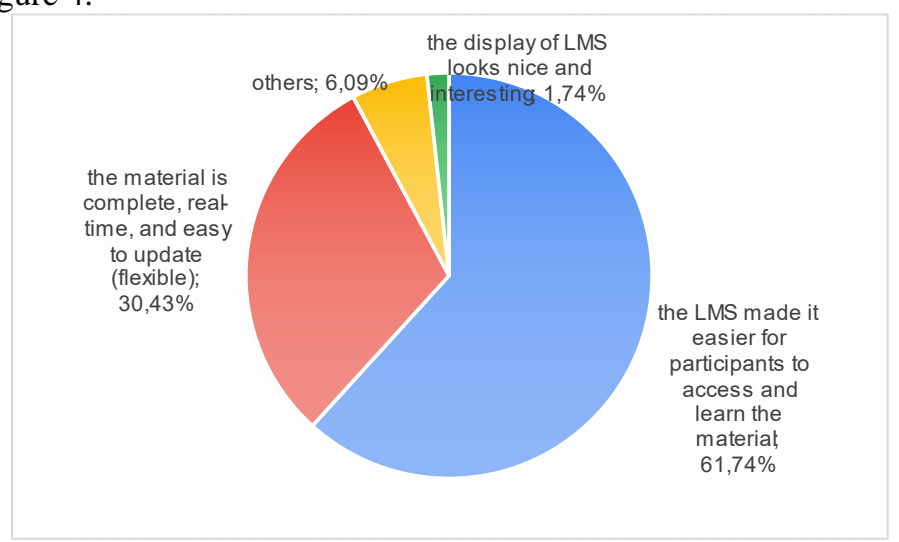

Figure 4. Advantages of LMS DL Functional Basic Tax Instructor

In Figure 4, it can be seen that more than $60 \%$ of participants said that the LMS made it easier for participants to access and learn the material. Another advantage is that the material is complete, real-time, and easy to update (flexible), as well as a friendly and attractive display. Other participants stated that this application is free, the LMS is creative, and the LMS production looks warm and exciting.

\section{Responses to the use of the LMS DL Functional Basic Tax Instructor}

Participants' responses to the LMS weakness are presented in Figure 5. 


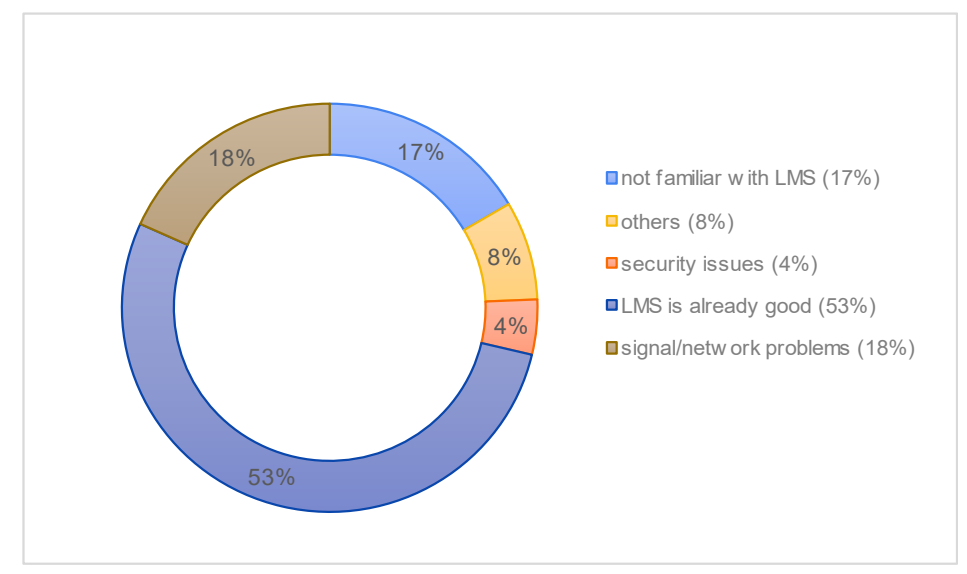

Figure 5. Responses to the weakness of the LMS

In general, participants mentioned that this LMS is already good. This opinion was given by more than $50 \%$ of the participants. An internet connection is an essential element for participants to access and learn about this LMS. Internet connection is interrupted or slowly becomes an obstacle in the implementation of this PJJ. Some of the participants were not familiar with learning using LMS. Security issues are also a concern for some learners, as LMS uses Google Sites easily accessible to anyone without using a password. Other stated participants include limited storage capacity in Drive, little Google Sites templates, and eyewatering learning.

\section{Participant graduation}

To show that the learning was successful, it was marked by the pass rate of the participants. The graduation of the participants in this study is as shown in Table 4.

Table 4. Participants Passing Grade

\begin{tabular}{clcccccc}
\hline No & $\begin{array}{l}\text { Graduation } \\
\text { Predicate }\end{array}$ & Pontianak & Manado & $\begin{array}{c}\text { Place } \\
\text { Yogyakarta }\end{array}$ & Jakarta & Amount & $\begin{array}{c}\text { Total } \\
\text { Percentage }\end{array}$ \\
\hline \multirow{2}{*}{1} & Pass & & & & & & \\
2 & Very Good & 23 & 30 & 28 & 23 & 104 & $88.14 \%$ \\
3 & Good & 1 & 0 & 4 & 9 & 14 & $11.38 \%$ \\
& Adequate & 0 & 0 & 0 & 0 & 0 & $0.00 \%$ \\
& Total & 24 & 30 & 32 & 32 & 118 & $100.00 \%$ \\
& Not Pass & 0 & 0 & 0 & 0 & 0 & $0.00 \%$ \\
\hline
\end{tabular}

Based on Table 4 , it can be seen that most of the participants $(88.14 \%)$ of participants successfully passed with perfect criteria (score above 90.00), and 14 participants (11.386\%) participants gave healthy (score above 80.00 to 90.00 ). None of the participants did pass. This indicates that the learning outcomes are excellent. 


\section{Participants suggestions}

The participant's suggestions for the LMS are shown in Table 5.

Table 5. Participants' Suggestions for the LMS DL Functional Basic Tax Instructor

\begin{tabular}{|c|c|c|}
\hline No & Suggestion & Percentage \\
\hline 1 & Good & $48.7 \%$ \\
\hline 2 & More attractive & $18.3 \%$ \\
\hline 3 & Always updated & $7.8 \%$ \\
\hline 4 & Easier access & $7.0 \%$ \\
\hline 5 & Added some feature & $6.1 \%$ \\
\hline 6 & Informed to use & $4.3 \%$ \\
\hline 7 & Accessible all the time & $3.5 \%$ \\
\hline 8 & To integrated with Learning Center & $2.6 \%$ \\
\hline 9 & More simplified & $1.7 \%$ \\
\hline
\end{tabular}

Most of the participants said the LMS was good. To further refine this LMS, the learning participants suggestions for improving it. Some participants wanted the appearance to be made more attractive. The appearance of the LMS is essential, especially for participants with the visual type of learners; with an attractive appearance, participants with this type are easier to learn the material. Some of the participants suggest constantly updating, accessing, adding some features, informed to use, accessible all the time, integrated with Ministry of Finance Learning Center (KLC/Semantik), and more straightforward.

Most participants of Functional Distance Learning of Basic Tax Instructor in the age range of 25-40 years or classified as Generations Y or Millennials, who are classified as generations can follow the learning by using LMS well, can even facilitate them in accessing and learning materials. On the other hand, Generation $X$ with the age of $>41$ years old is not very familiar with LMS and needs information in advance in the use of this LMS, although Generation X participants also feel the benefits of LMS in the form of complete learning materials, realtime and flexible. Overall, the LMS has several advantages : it is easier for participants to access and learn the material; the LMS provides complete, real-time, and flexible material, and has a nice and attractive look; and the LMS is creative, good, interesting, and free. The constraints in the use of LMS is mostly due to internet network constraints, so participants have difficulty accessing or slow and some participants still experience problems and some are worried about security problems. For future LMS enhancements, the LMS display is expected to be more attractive with materials that stay up to date, lighter access, added some feature, accessible for all the time, it integrated with Kemenkeu Learning Center (KLC), and make more simple.

\section{Reference}

[1] Warsita B. Pendidikan Jarak Jauh. 1st ed. Bandung: PT Remaja Rosdakarya; 2011.

[2] Bozkurt A. From Distance Education to Open and Distance Learning: A Holistic Evaluation of History, Definitions, and Theories. Handb. Res. Learn-Age Transhumanism Copyr., Anadolu University, Turkey; 2019, p. 22.

[3] Cavus N. Distance Learning and Learning Management Systems. Procedia - Soc Behav Sci 2015;191:872-7. https://doi.org/10.1016/j.sbspro.2015.04.611. 
[4] Iskandar K, Thedy D, Alfred J, Yonathan. Evaluating a Learning Management System for BINUS International School Serpong. Procedia Comput Sci 2015;59:205-13. https://doi.org/10.1016/j.procs.2015.07.556.

[5] Soykan F, Şimşek B. Examining studies on learning management systems in SSCI database: A content analysis study. Procedia Comput Sci 2017;120:871-6. https://doi.org/10.1016/j.procs.2017.11.320.

[6] Raman R, Nurtanto M, Khalifah N. Design And Development E-Learning System By Learning Management System (LMS) In Vocational Education 2020;9:5.

[7] Setyawan B. Pengembangan Media Google Site dalam Bimbingan Klasikal di SMAN 1 Sampung. Nusant Res J Has-Has Penelit Univ Nusant PGRI Kediri 2019;6:78-87. https://doi.org/10.29407/nor.v6i2.13797.

[8] Juliarini A, Kurachman T. Pembelajaran Jarak Jauh Penyuluh Perpajakan Dalam Pembelajaran Normal Baru. J Transform Adm-LAN-Aceh 2020;10:17.

[9] Llantos OE, Justina E. Estuar MR. my.Eskwela: Designing An Enterprise Learning Management System to Increase Social Network and Reduce Cognitive Load. Procedia Comput Sci 2018;138:595602. https://doi.org/10.1016/j.procs.2018.10.080.

[10] Aldi A, Chowdhury H, Kootsookos A, Alam F, Allhibi H. Utilization of Learning Management Systems (LMSs) in the higher education system: A case review for Saudi Arabia. Energy Procedia 2019;160:731-7. https://doi.org/10.1016/j.egypro.2019.02.186.

[11] Zheng Y, Wang J, Doll W. The impact of organizational support, technical support, and selfefficacy on faculty perceived benefits of using learning management system. Behav Inf Technol 2018;37.

[12] Murshid K, Wakim P. A Learning Management System Enhanced with the Internet of Things Applications. J Educ Learn 2018;7:23. https://doi.org/10.5539/jel.v7n3p23.

[13] Mukti WM. Media Pembelajaran Fisika Berbasis Web Menggunakan Google Sites Pada Materi Listrik Statis 2020:9.

[14] Maheshwary P, Bhandari A. Case-Study-Google for Education. SSRN Electron J 2019. https://doi.org/10.2139/ssrn.3375711.

[15] Rusdi. Penelitian Desain dan Pengembangan Kependidikan (Konsep, Prosedur, dan Sintesis Pengetahuan Baru). 1st ed. Depok: PT Raja Grafindo Persada; 2018.

[16] Nichols Hess A, Greer K. Designing for Engagement: Using the ADDIE Model to Integrate High-Impact Practices into an Online Information Literacy Course. Comminfolit 2016;10:264. https://doi.org/10.15760/comminfolit.2016.10.2.27.

[17] Cahyadi R. Pengembangan Bahan Ajar Berbasis Addie Model. Halaqa Islam Educ J 2019;3:35. https://doi.org/10.21070/halaqa.v3i1.2124.

[18] Kumbhar KN. Creating a Library portal by using Google Sites. J Adv Libr Inf Sci Vol IX - Issue No 2 April-June 202 2020; IX.

[19] Awuah LJ. Supporting 21st-Century Teaching and Learning: The Role of Google Apps for Education (GAFE). J Instr Res 2015;4.

[20] Widodo S. Implementing Google Apps for Education as Learning Management System in Math Education. J Phys Conf Ser 2017;895:012053. https://doi.org/10.1088/1742-6596/895/1/012053. 